\title{
Evaluation of Indicators of Environmental Sensitivity with Respect to Bats and their Native Habitats near Albeni Falls Dam and Lake Pend Oreille, Idaho
}

\author{
Prepared for: \\ U.S. Army Corps of Engineers \\ Agreement Number: W912Hz-16-2-0023 \\ Prepared by: \\ Daniel A. Bachen, Alexis McEwan, Braden Burkholder \\ Montana Natural Heritage Program \\ Natural Resource Information System \\ Montana State Library \\ January, 2018
}

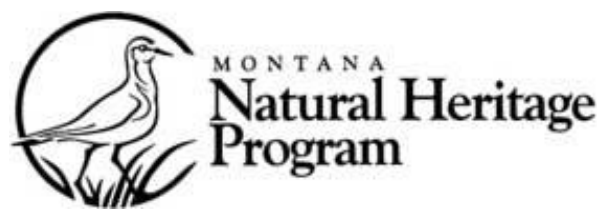




\title{
Evaluation of Indicators of Environmental Sensitivity with Respect to Bats and their Native Habitats near Albeni Falls Dam and Lake Pend Oreille, Idaho
}

\author{
Prepared for: \\ U.S. Army Corps of Engineers \\ Agreement Number: \\ W912Hz-16-2-0023
}

Prepared by:

Daniel A. Bachen, Alexis McEwan, Braden Burkholder
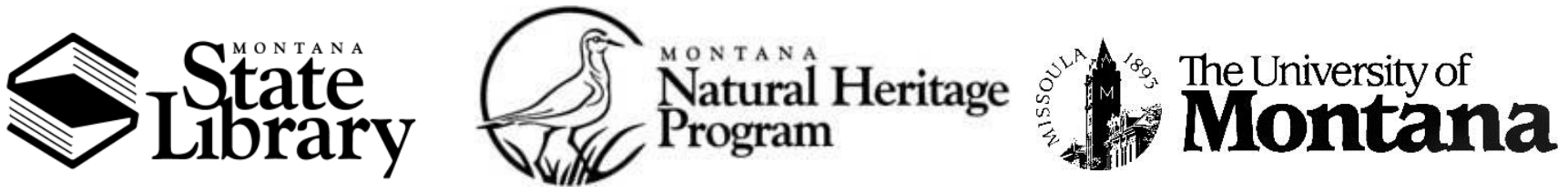

(C) 2017 Montana Natural Heritage Program

P.O. Box $201800 \bullet 1515$ East Sixth Avenue • Helena, MT 59620-1800 • 406-444-3290 
This document should be cited as follows:

Bachen, D.A., A.L. McEwan, B. Burkholder. 2018. Evaluation of Indicators of Environmental Sensitivity with Respect to Bats and their Native Habitats near Albeni Falls Dam and Lake Pend Oreille, Idaho. Montana Natural Heritage Program, Helena, Montana. 18 p. plus appendices. 


\section{EXECUTIVE SUMmary}

Persistence of populations of bats may be threatened by loss of roosting sites, elimination of insect prey, collision or drowning hazards at sites where they forage, drink, and mate, and a lack of baseline information on distribution and habitat use that are available to resource managers. However, in recent years, concerns have shifted focus to White-Nose Syndrome (WNS) and wind turbine development. WNS resulting from the cold adapted fungus Pseudogymnoascus destructans has killed an estimated 5.7 to 6.7 million bats in eastern North America since 2006

Given the recent detection of WNS in Washington, establishing baseline information for species in areas of the Pacific Northwest where WNS is not yet present is critical for conservation and management of these species. Acoustic detectors are powerful tools for establishing species presence and habitat use. Without acoustic monitoring surveys in this region, the U.S. Army Corps of Engineers (ACOE) will lack information needed to mitigate potential impacts to bats from WNS and make informed management decisions.

To address these information needs, we deployed acoustic detector/recorders on ACOE managed lands in proximity to Albine Falls Dam located on the Pend Oreille River. Our goals were to determine which species are present in this area, provide baseline data that can be used for WNS surveillance, and to assess the impacts of this disease and other natural or anthropogenic threats to bat populations in this area, and provide management recommendations for conservation of the species found within ACOE managed lands.

At or upstream of the Albeni Falls Dam on the Pend Oreille River, we selected 13 sites on lands managed by the U.S. Army Corps of Engineers to conduct this project. Three detector/recorder units were rotated between these sites throughout the active season beginning in April and ending in September. Each site was surveyed between two and three times as time and logistic considerations allowed (Table 1 ). In total 26 surveys were conducted across all sites. However, due to technical issues, detectors did not collect any information during three of these surveys. A single detector was deployed over the winter of 2016-2017 in proximity to Albeni Falls Dam

Between September 2016 and September 2017 , a total of 21,811 bat call sequences were recorded with a 9.9 percent autoidentification to species by Sonobat 4.2.1 software. Overall rates of autoidentification were lower than detectors placed across Montana, Idaho, and North and South Dakota which average of 23.7 percent. Across all sites, average nightly passes by bats increased through July and decreased into September. Recorded activity during the winter was low, which is similar to patterns observed at sites across Idaho, Montana, and the Dakotas.

Of the 21,811 recorded call sequences, we hand reviewed 2,320 with the goal of determining species presence by site and recording period. Between April and September, 10 species were identified within the study area: Hoary Bat (Lasiurus cinereus), Big Brown Bat (Eptiscus Fuscus), Silver-haired Bat (Lasionycteris 
noctivagans), Townsend's Big-eared Bat (Corynorhinus townsendii), California Myotis (Myotis californicus), Western Small-footed Myotis (Myotis ciliolabrum), Long-eared Myotis (Myotis evotis), Fringed Myotis (Myotis thysanodes), Little Brown Myotis (Myotis lucifugus), Yuma Myotis (Myotis yumanensis). Only four species commonly found in Idaho were not confirmed within the study area: Spotted Bat (Euderma maculatum), Pallid Bat (Antrozous pallidus), Long-legged Myotis (Myotis volans), and Canyon Bat (Parastrellus hesperus). Spotted, Pallid, and Canyon bats are unlikely to be present because they require specialized habitat not found in the area. Conversely, Long-legged Myotis may occur within the area, but are difficult to have definitive confirmation via acoustic methods.

Of the 10 species detected at sites within the project area, three have been shown to develop WNS when exposed to Pd. These species are the Big Brown Bat, Little Brown Myotis, and Yuma Myotis. Additionally, the Silver-haired Bat and Townsend's Big-eared Bat have been shown to carry Pd, but not exhibit symptoms of WNS. The remaining Myotis species: California, Long-eared, Western Small-footed, and Fringed have not been shown to carry Pd or develop WNS. Rather than indicating immunity to $\mathrm{Pd}$, the lack of detections of individuals with this disease is likely a result of their western distribution that has not overlap with affected areas. As many other Myotis species are impacted by WNS, it is probably best to consider these species as susceptible until proven otherwise.

Future surveys should seek to determine if the species found during this work are still present within the study area. Although the short-term deployments make the activity data difficult to use as a baseline, average bat passes per night may be an adequate metric for future monitoring if the disease has a significant negative impact. If sites that reduce the likelihood of vandalism can be found, we recommend that future acoustic monitoring include long-term stations capable of gathering robust activity data across both the active and hibernation seasons. As both the Townsend's Big-eared Bat and Long-legged Myotis are difficult to detect with acoustic methods, targeted mist net surveys of creeks and ponds off of the river or lake and flight corridors within forested areas should be considered as well as age and sex data on all species. Finally, projects focusing on identifying active season roosts within both natural and artificial structures, hibernacula, and monitoring known roosts to provide additional baseline data to inform management decisions.

Management of roost features used by bats within ACOE managed lands near Albeni Falls Dam is likely to have the biggest impact on local populations. Roosts occur in a variety of natural and anthropogenic features including crevices and cracks in rock outcrops, caves, and both live and dead trees, and buildings, bridges, and mines. Based on the species we determined to be present within the study area, literature documenting roost preferences, and life history of these species, we recommend the following actions for species conservation within the study area: 
1. Maintain potential roost trees including large diameter trees, snags and partially dead trees that provide cavities or loose bark for animals to roost in unless they pose a hazard to people in the immediate area. If removal is necessary, wait until the late fall or winter to remove trees suspected or known to support roosting bats.

2. Before modification of any buildings or bridges, conduct surveys to establish whether the structures are used as roosts. These surveys could include searching for guano deposits and urine staining on the interior or exterior of structures, and examining crevices and sheltered areas for roosting bats. If feasible conduct exit counts at dusk at potential exit points from the structure. If bats are found and exclusion is desired, follow best practices for exclusion and place alternative roost structures (bat boxes) in the local area to compensate for the loss of roosting habitat.

3. Surveys to determine bat use of other potential roosts including but not limited to rock outcrops, caves, and mines should be conducted prior to any modification.

4. Avoid disturbance of known maternity roosts between May and July and known hibernaculum between October and April. 


\section{ACKNOWLEDGEMENTS}

We extend considerable thanks and appreciation to Betsy Hull and other U.S. Army Corps of Engineers staff for placement and maintenance of acoustic detectors. Bryce Maxell for providing feedback on project design and implementation. Scott Blum and other Montana Natural Heritage Program Staff for formatting the data and appending it to the Montana Natural Heritage Program's central animal observation database. We thank the U.S. Army Corps of Engineers for providing funding and guidance for this project.

This project was supported by an agreement between the U.S. Army Corps of Engineers and the Montana Natural Heritage Program, a cooperative program of the Montana State Library and the University of Montana (W912Hz-16-2-0023) 


\section{TABLE OF CONTENTS}

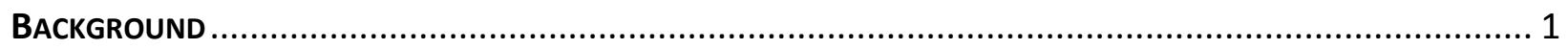

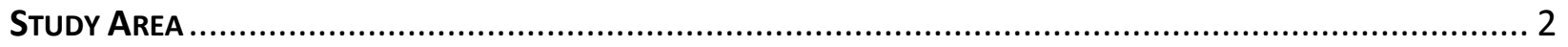

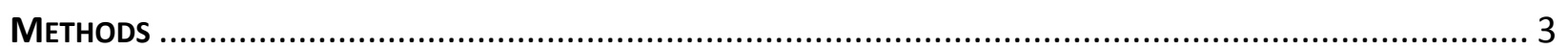

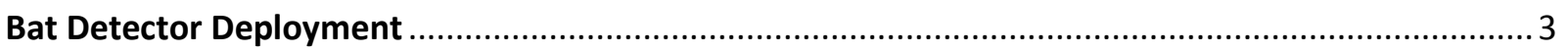

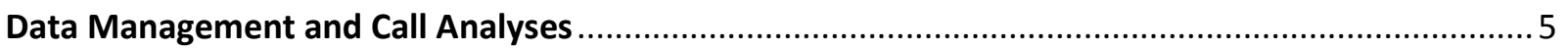

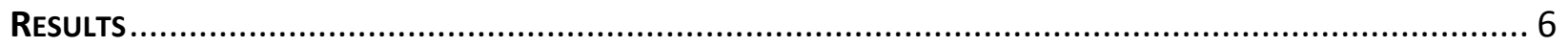

Total Volume of Bat Passes and Auto-Identification Rates ......................................................... 6

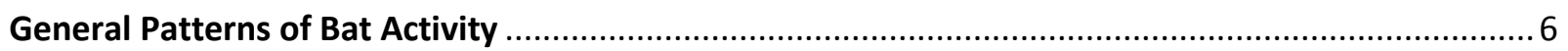

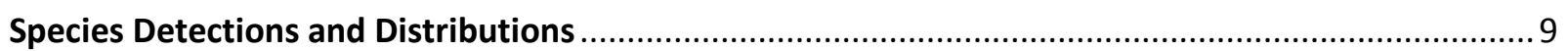

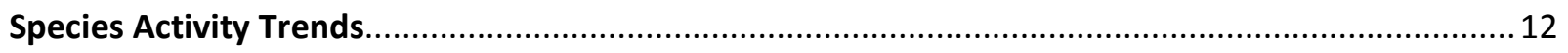

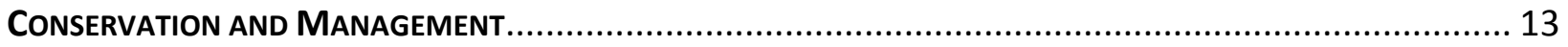

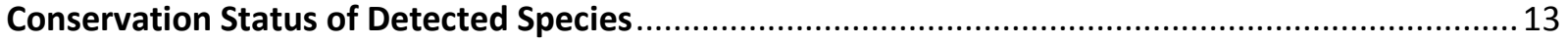

Implications for White-Nosed Syndrome Monitoring ….............................................................. 13

Conservation of Roosts and Other Landscape Features Important for Bats................................... 14

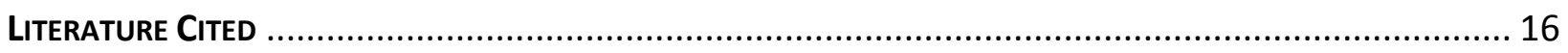

\section{TABLES}

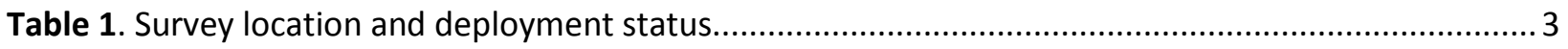

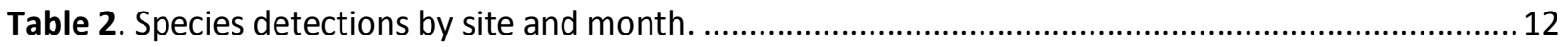

\section{FIGURES}

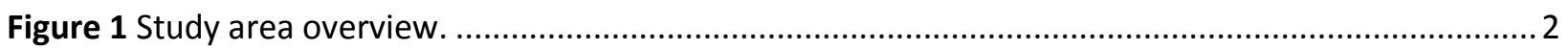

Figure 2 Average number of calls recorded across the study area by month.......................................... 6

Figure 3 Total bat passes for all species recorded across long-term acoustic network............................. 7

Figure 4 Average number of call sequences for all species per night by site ........................................... 8

\section{APPENDICES}

Appendix 1 Average Nightly Bat Passes by Site and Month .............................................. 1-1

Appendix 2 Species Detections Across Acoustic Monitoring Sites ....................................... 2-1 


\section{BACKGROUND}

Persistence of populations of bats may be threatened by loss of roosting sites, elimination of insect prey, collision or drowning hazards at sites where they forage, drink, and mate, and a lack of baseline information on distribution and habitat use that are available to resource managers. However, in recent years, concerns have shifted focus to White-Nose Syndrome (WNS) (Blehert et al. 2011) and wind turbine development (Kunz et al. 2007, Arnett et al. 2008). Dramatic increases in mortality posed by these threats are especially significant to bat populations because bats are long-lived and have only 1 or 2 young per year (Barclay and Harder 2003).

WNS resulting from the cold adapted fungus Pseudogymnoascus destructans has killed an estimated 5.7 to 6.7 million bats in eastern North America since 2006 (Lorch et al. 2011, USFWS News Release January 17, 2012). As a result, the extinction of Little Brown Myotis (Myotis lucifugus) is predicted in that region by 2026 (Frick et al. 2010). Additionally, M. lucifugus, Northern Myotis (M. septentrionalis), and Tri-colored Bat (Perimyotis subflavus) have all been recommended for emergency listing under Schedule 1 of Canada's Species at Risk Act (COSEWIC February 3, 2012). In the United States $M$. septentrionalis has been listed as threatened under the United States

Endangered Species Act (ESA) (U.S. Fish and Wildlife Service 2016), and M. lucifugus has been petitioned for emergency listing under the ESA (Kunz et al. 2010). Prior to 2016, the pathogen was only documented east of the Rockies and as far west as Nebraska. However, in March of 2016 a bat showing symptoms of WNS was found in Washington, representing the first time the pathogen has been documented in the Pacific Northwest (USFWS News Release March 31, 2016). P. destructans has progressed westward to at least Nebraska and it is unknown how widespread the fungus is in Washington State. At least three bat species susceptible to WNS are found in Northern Idaho: Big Brown Bat (Eptesicus fuscus), Yuma Myotis ( $M$. yumanensis) and Little Brown Myotis are (Blehert et al. 2011, Washington Department of Fish and Wildlife Press Release May 2017).

Given the recent detection of WNS in Washington, establishing baseline information for species in areas of the Pacific Northwest where WNS is not yet present is critical for conservation and management of these species. Acoustic detectors are powerful tools for establishing species presence and habitat use (Britzke et al. 2013). Without acoustic monitoring surveys in this region, the U.S. Army Corps of Engineers (ACOE) will lack information needed to mitigate potential impacts to bats from WNS and make informed management decisions.

To address these information needs, we deployed acoustic detector/recorders on ACOE managed lands in proximity to Albine Falls Dam located on the Pend Oreille River. Our goals were to determine which species are present in this area, provide baseline data that can be used for WNS surveillance, 
and to assess the impacts of this disease and other natural or anthropogenic threats to bat populations in this area, and provide management recommendations for conservation of the species found within ACOE managed lands.

\section{STUDY AREA}

At or upstream of the Albeni Falls Dam on the Lake Pend Oreille, we selected 13 sites on lands managed by the U.S. Army Corps of Engineers to conduct this project. The landscape surrounding the river is predominately conifer forest with sparse wetlands, and fields. Areas of willows (Salix spp.) or alder (Alnus spp.) occur at the interface between the river and uplands. Elevations across the study area range from 620 and $630 \mathrm{~m}$ above sea level. Relatively mild summer temperatures and cool wet winters characterize the climate of the local area (Arguez et al. 2012).

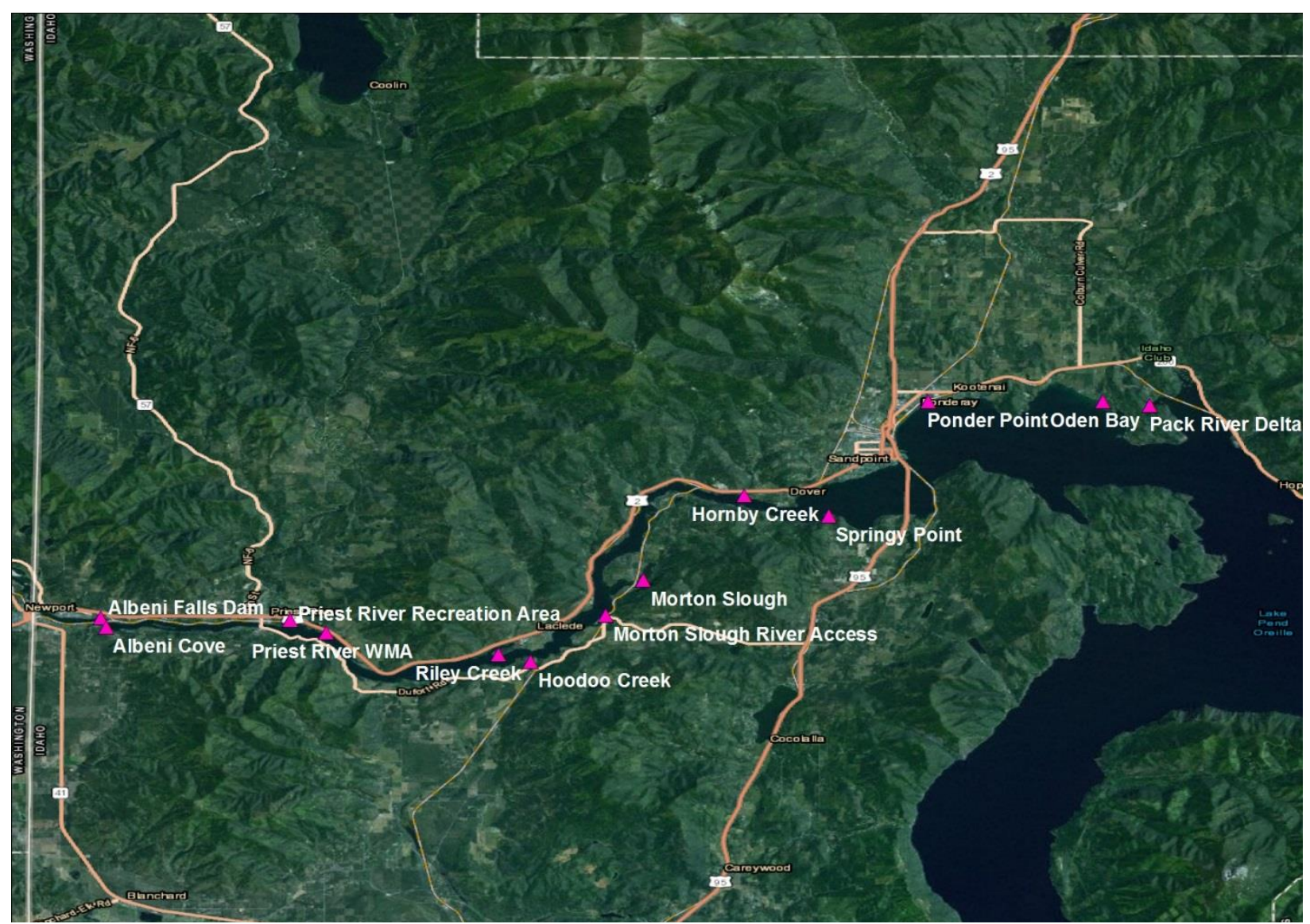

Figure 1 Location and name of sites surveyed during the winter of 2016-2017 (Albeni Falls Dam) and Summer 2017 (all other sites). Sites were established along the interface between the river/reservoir and adjacent riparian or upland areas. 


\section{MethOdS}

\section{Bat Detector Deployment}

Three detector/recorder units were rotated between 12 sites throughout the active season beginning in April and ending in September. Each site was surveyed between two and three times as time and logistic considerations allowed (Table 1). In total 26 surveys were conducted across all sites. However, due to technical issues, detectors did not collect any information during three of these surveys. A single detector was deployed over the winter of 2016-2017 in proximity to Albeni Falls Dam.

Table 1. Information for each survey describing the site name, coordinates (WGS 84) of each site, detector type, and deployment dates for the 27 acoustic surveys. Location names with asterisks denote surveys where bat passes were not recorded due to technical issues.

\begin{tabular}{|c|c|c|c|c|c|}
\hline Location & Latitude & Longitude & Detector Type & $\begin{array}{c}\text { Date } \\
\text { Deployed }\end{array}$ & $\begin{array}{c}\text { Date } \\
\text { Retrieved }\end{array}$ \\
\hline Albeni Falls Dam & 48.180011 & -117.000969 & SM2Bat+ & $2016-09-22$ & $2017-04-13$ \\
\hline Albeni Cove & 48.17485 & -116.998033 & SM2Bat+ & $2017-05-18$ & $2017-06-12$ \\
\hline Albeni Cove & 48.17485 & -116.998033 & SM2Bat+ & $2017-08-02$ & $2017-08-16$ \\
\hline Hoodoo Creek & 48.155017 & -116.75495 & SM2Bat & $2017-05-18$ & $2017-06-12$ \\
\hline Hoodoo Creek & 48.155017 & -116.75495 & SM2Bat & $2017-08-02$ & $2017-08-16$ \\
\hline Hornby Creek* & 48.25015 & -116.632467 & SM2Bat+ & $2017-05-02$ & $2017-08-02$ \\
\hline Hornby Creek & 48.25015 & -116.632467 & SM2Bat+ & $2017-07-15$ & $2017-09-02$ \\
\hline Morton Slough & 48.201717 & -116.690283 & SM2Bat & $2017-06-12$ & $2017-07-01$ \\
\hline Morton Slough & 48.201717 & -116.690283 & SM2Bat & $2017-08-16$ & $2017-09-02$ \\
\hline $\begin{array}{c}\text { Morton Slough } \\
\text { River Access }\end{array}$ & 48.1813 & -116.711967 & SM2Bat+ & $2017-04-13$ & $2017-05-02$ \\
\hline $\begin{array}{c}\text { Morton Slough } \\
\text { River Access }\end{array}$ & 48.1813 & -116.711967 & SM2Bat & $2017-07-01$ & $2017-07-15$ \\
\hline $\begin{array}{c}\text { Priest River } \\
\text { Recreation Area }\end{array}$ & 48.178967 & -116.89235 & SM2Bat+ & $2017-05-02$ & $2017-05-18$ \\
\hline $\begin{array}{c}\text { Priest River } \\
\text { Recreation Area }\end{array}$ & 48.178967 & -116.89235 & SM2Bat+ & $2017-07-15$ & $2017-08-02$ \\
\hline $\begin{array}{c}\text { Priest River } \\
\text { Recreation Area }\end{array}$ & 48.178967 & -116.89235 & SM2Bat+ & $2017-09-05$ & $2017-09-28$ \\
\hline $\begin{array}{c}\text { Oden Bay* } \\
\text { Oden Bay }\end{array}$ & 48.3038 & -116.426983 & SM2Bat+ & $2017-05-18$ & $2017-06-12$ \\
\hline Pack River Delta & 48.301467 & -116.4003 & SM2Bat+ & $2017-06-12$ & $2017-07-01$ \\
\hline Pack River Delta & 48.301467 & -116.4003 & SM2Bat+ & $2017-08-16$ & $2017-09-02$ \\
\hline $\begin{array}{c}\text { Ponder Point* } \\
\text { Ponder Point }\end{array}$ & 48.30405 & -116.527267 & SM2Bat+ & $2017-04-13$ & $2017-05-02$ \\
\hline $\begin{array}{c}\text { Priest River } \\
\text { WMA* }\end{array}$ & 48.30405 & -116.527267 & SM2Bat+ & $2017-07-01$ & $2017-07-15$ \\
\hline
\end{tabular}




\begin{tabular}{|c|c|c|c|c|c|}
\hline Location & Latitude & Longitude & Detector Type & $\begin{array}{c}\text { Date } \\
\text { Deployed }\end{array}$ & $\begin{array}{c}\text { Date } \\
\text { Retrieved }\end{array}$ \\
\hline Priest River WMA & 48.1714 & -116.871833 & SM2Bat+ & $2017-07-01$ & $2017-07-15$ \\
\hline Priest River WMA & 48.1714 & -116.871833 & SM2Bat & $2017-09-05$ & $2017-09-28$ \\
\hline Riley Creek & 48.1591 & -116.773417 & SM2Bat+ & $2017-06-13$ & $2017-06-30$ \\
\hline Riley Creek & 48.1591 & -116.773417 & SM2Bat+ & $2017-08-16$ & $2017-09-05$ \\
\hline Springy Point & 48.238283 & -116.58425 & SM2Bat & $2017-05-02$ & $2017-05-18$ \\
\hline Springy Point & 48.238283 & -116.58425 & SM2Bat & 2017-07-15 & 2017-08-02 \\
\hline
\end{tabular}

Each SM2Bat or SM2 Bat+ ultrasonic detector/recorder (Wildlife Acoustics, Maynard, MA, USA) was deployed, monitored, and maintained with the equipment, supplies, settings, and protocols listed in Montana's Bat and White-Nose Syndrome Surveillance Plan and Protocols 2012- 2016 (Maxell 2015). Due to concerns of vandalism, we chose to reduce the visual profile of our detector/recorder stations by using internal D-cell batteries as a power source rather than our standard long-term detector power supply which uses a 12-volt car battery and solar panel. Use of internal batteries restricted operating time for detectors to less than a week per deployment. The only exception was the station placed at the dam site, which was set up following our standard long-term protocol (Maxell 2015). This station was secured behind a high fence, reducing the likelihood that it would be vandalized and therefore was suitable for long-term deployment.

A variety of factors influence the detection and recorded quality of a bat echolocation call. These include sensitivity of the individual microphone, temperature, humidity, wind speed, and frequency, amplitude, distance, and directionality of echolocation calls emitted by bats (Parsons and Szewczak 2009, Agranat 2014). The energy of sounds spreading in all directions diminishes by one fourth for every doubling of distance because the surface area of a sphere is related to the square of its radius. Furthermore, higher frequency sounds are diminished over shorter distances because of atmospheric absorption (Parsons and Szewczak 2009, Agranat 2014). Testing of the SMX-US microphone used in this study indicates that bats emitting frequencies in the range of $20 \mathrm{kHz}$ should be detected at distances of 24 to 33 meters from the microphone while those emitting frequencies in the range of $40 \mathrm{kHz}$ should be detected at distances of 18 to 22 meters (Agranat 2014). These distances are the radii of the relevant spheres of detection around microphones when they are at full sensitivity. However, we know that sensitivity varied over time by an unknown magnitude as a result of precipitation and freezing events, some of which permanently reduced the sensitivity of microphones. 


\section{Data Management and Call Analyses}

Acoustic file recordings, in both original WAC and processed WAV formats, are stored in the Montana Bat Call Library. These are housed on a series of 15-20

Terabyte Drobo 5D and 5N storage arrays at the Montana State Library as well as a secondary offsite location to protect against catastrophic loss. Acoustic analysis results and temperature files were all processed and combined within SQL database tables in accordance with the general work flow pattern for data management and analysis outlined in the text and in Appendices 8-10 of Maxell (2015). Bat call sequences were analyzed with the goal of definitively identifying individual species presence by site and survey period in accordance with the Echolocation Call Characteristics of Montana Bats and Montana Bat Call Identification materials in Appendices 6 and 7 of Montana's Bat and White-Nose Syndrome Surveillance Plan and Protocols 2012- 2016 (Maxell 2015). 


\section{RESULTS}

Total Volume of Bat Passes and AutoIdentification Rates

Between September 2016 and September 2017 , a total of 21,811 bat call sequences were recorded with a 9.9 percent autoidentification to species by Sonobat 4.2.1 software. Overall rates of autoidentification were lower than at other detectors placed across Montana, Idaho, and North and South Dakota which average of 23.7 percent (Montana Natural Heritage Program Acoustic Survey Data 2017). This discrepancy could be due to placement of detectors in proximity to forest edges, which were unavoidable within the study area, or some other unknown factor.

\section{General Patterns of Bat Activity}

Although our short-term deployments are not suitable for use in a robust assessment and comparison of activity levels, we can make general comparisons across and between sites. However, as detectors only record for short periods (days), recorded activity could be influenced by environmental variables that affect bat activity such as precipitation, wind, and moon phase, and confound assessment of bat activity at the site. Across all sites, average nightly passes by bats increased through July and decreased into September (Figure 2). Recorded activity during the winter was low, which is similar to patterns observed at sites across Idaho, Montana, and the Dakotas (Figure 3).

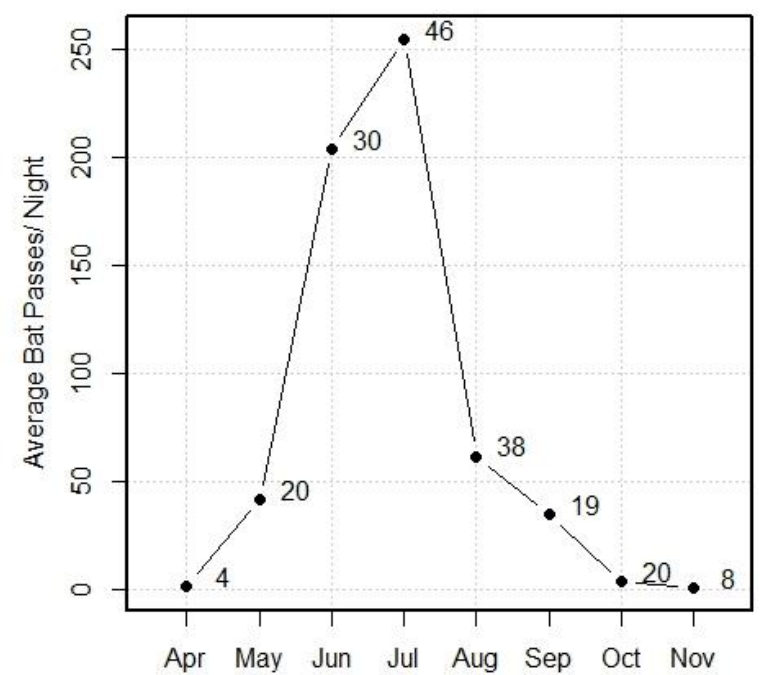

Figure 2 The average number of calls recorded across the study area by month. The number of recording nights within each month is shown adjacent to each point.

The relative number of bat passes recorded during the late summer and early fall across the study area differed from the regional network trend. The Albeni Falls area had significantly lower amount of calls recorded in August relative to June and July. This is atypical to other sites across the region. This trend may be related to spatial bias introduced through the use of short-term deployments and uneven sampling of sites over time. If these data show an actual biological trend, it may indicate local migration or change in habitat use by bats exploiting resources elsewhere in the surrounding area. In the Northern Rocky Mountains, young of all species are initially captured in late July, as juveniles become flighted (Bachen et al. 2016). Reduced activity coinciding with volant young may indicate that females and pups leaving their maternity colonies and migrating away from the river or lake for some unknown 
reason. To assess the validity of this trend, long-term acoustic and mist net surveys are required.

Given the study design considerations, sites in the central region of the study area appear to have consistently higher average nightly activity of all species (Figure 5). As all sites were not sampled at the same time, these results should be viewed with caution. However, all high activity sites were clustered in the center of the study area, which supports a biological base for this trend.

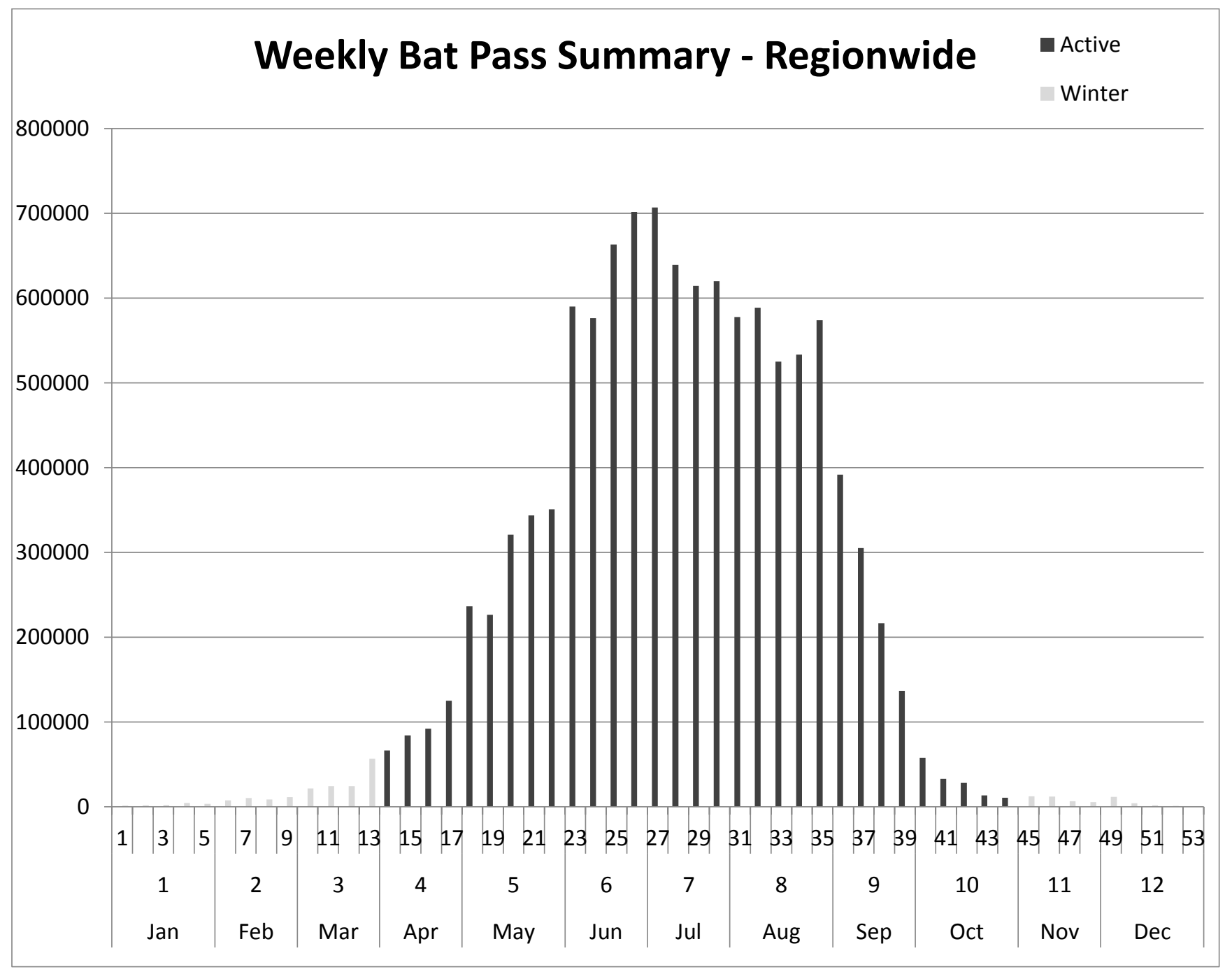

Figure 3 The total number of bat passes for all species recorded each week across a network of 76 detectors deployed in Montana, Idaho, North Dakota, and South Dakota. All stations were deployed for over two years. This aggregated year-round data provides insight into variation in activity levels across the year. 


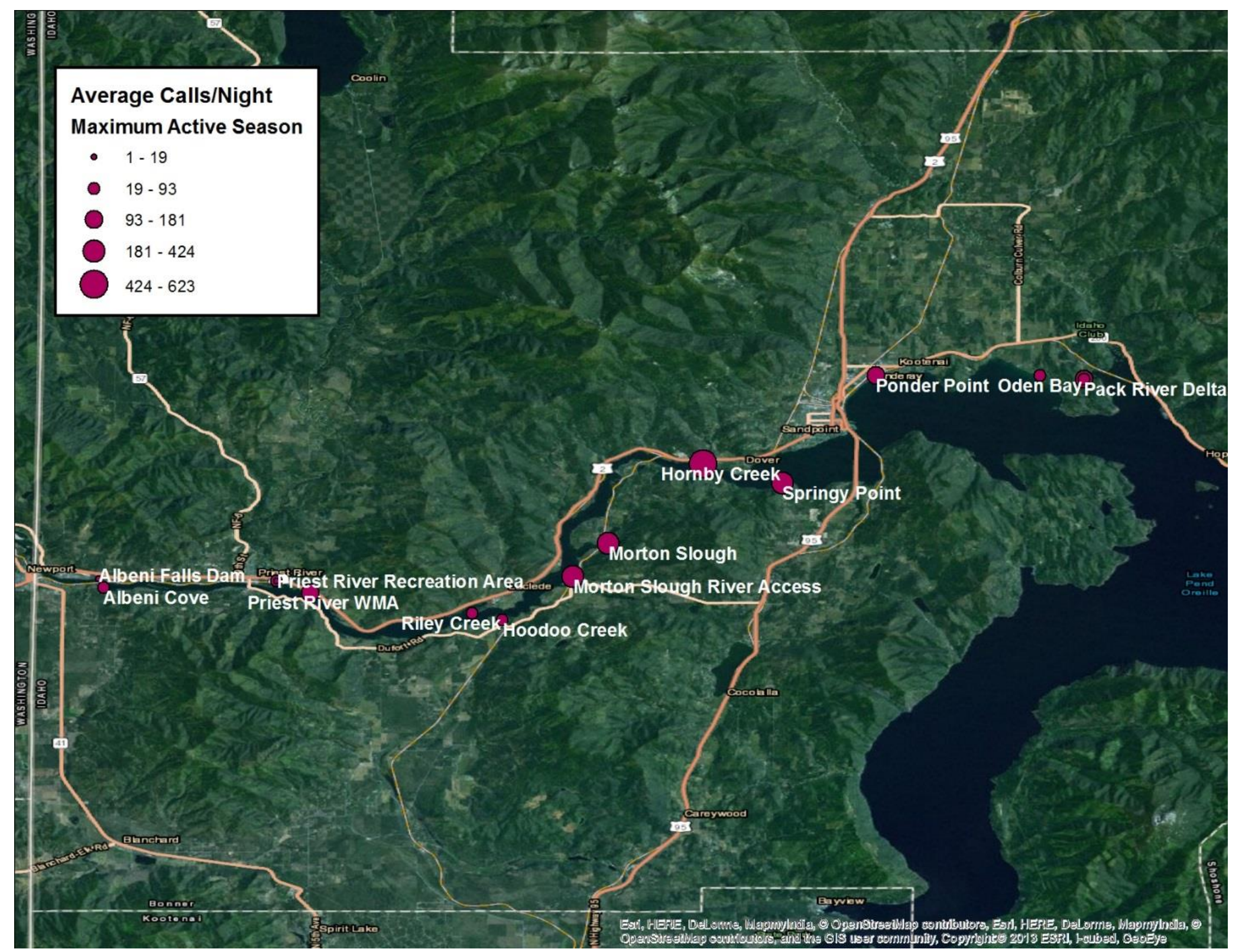

Figure 4 The average number of call sequences for all species per night at each site recorded during the active season 2017. Morton Slough sites, Hornby Creek, and Springy point all have relatively high levels of activity compared to surrounding stations. 


\section{Species Detections and Distributions}

Of the 21,811 recorded call sequences, we hand reviewed 2,320 with the goal of determining species presence by site and survey period. Between April and September, 10 species were identified within the study area. Only four species commonly found in Idaho were not confirmed within the study area: Spotted Bat (Euderma maculatum), Pallid Bat (Antrozous pallidus), Long-legged Myotis (Myotis volans), and Canyon Bat (Parastrellus hesperus). Spotted, Pallid, and Canyon bats are unlikely to be present because they require specialized habitat not found in the area. Conversely, Long-legged Myotis may occur within the area, but are difficult to have definitive confirmation via acoustic methods (Maxell 2015).

Although we list the presence of each species within the area by site, given the limited ability of short-term detector deployments, lack of detection should not be interpreted as species absence. Some species are more easily identified or produce distinctive call sequences more frequently than others (e.g. Hoary Bat (Lasiurus cinereus) versus Long-legged Myotis, Maxell 2015). Therefore, the number of sites where detection of a species occurred may be resultant of sampling and survey methods rather than true presence. Given the similarity and geographic connectivity of sites along the river/reservoir, it is plausible that any species detected at one site may also be found at others. Consequently, the best interpretation of these data are that all confirmed species are present within the study area.
Hoary Bats were hand-confirmed at five sites: Hoodoo Creek, Morton River Recreation Area, Morton River Slough, Priest River Wildlife Management Area (WMA) and Springy Point. The first detection occurred in June and the species was confirmed as present through September. These detection dates are consistent with data collected at long-term stations in western Montana. Hoary bats are known to migrate to climates that are more favorable in the winter (Shump and Shump 1982). Based on these data, similar behavior occurs within the study area. This species primarily roosts on the branches and foliage of trees, (Shump and Shump 1982), and roosting habitat is found across the study area.

Big Brown Bats were confirmed at a single site, the Priest River Recreation Area. This species is likely more common across the area than this single detection would suggest. The calls of Big Brown Bats are often similar to Silver-haired Bats, which makes definitive confirmation of species presence using acoustic methods difficult. Call sequences automatically identified by Sonobat Software as Big Brown Bats were present at two additional sites, Albeni Cove and Hoodoo Creek, and may be present at these additional locations. Given the species propensity for roosting in buildings as well as bridges and natural features (reviewed in Maxell 2015 Appendix 5), suitable habitat exists across much of the study area, but targeted mist net or roost surveys may be needed to document this species at additional sites within the area.

The presence of Silver-haired Bats was confirmed at five sites: Morton Slough, 
Priest River Recreation Area, Priest River WMA, Riley Creek, and Springy Point. This species was first detected in May and was present each month through September. In northern areas overwintering strategies are poorly understood for this species, but it is possible that it may remain in the vicinity of the study area year round. In Montana echolocation calls have been recorded throughout the winter during periods of relatively warm temperatures (Montana Natural Heritage Program Acoustic Data 2017), suggesting the species remains in the region through the winter. Data to assess whether the species pursues a similar strategy in this area of Idaho are lacking. Deployment of long-term acoustic monitoring stations could help determine if Silver-haired Bats remain in the area year round.

A single call sequence from a Townsend's Big-eared Bat (Corynorhinus townsendii) was recorded at the Morton River Access Site in July of 2017. Due to its low call intensity and habit of foraging in or near vegetation, detectors infrequently record this species, even in areas where it is present (Maxell 2015). Townsend's Bigeared Bats have been previously documented infrequently in similar habitat in adjacent areas of Montana (MTNHP Point Observation Database), but without target roost surveys, it is difficult to determine how widespread or abundant the species is within the area. The species may use caves, rock crevices, and mines as both active season and winter roosts, and buildings during the active season as well (reviewed in Maxell 2015 Appendix 5).
The presence of California Myotis (Myotis californicus) was confirmed at six sites: Morton River Recreation Area, Morton River Slough, Pack River Delta, Priest River Recreation Area, Priest River WMA, and Springy Point. The species was present across the active season, beginning in May and last recorded in September. Cracks and crevices in rock outcrops as well as caves and mines are thought to be used as hibernacula within this region (as reviewed in Maxell 2015). If suitable hibernacula are present within the study area, California Myotis may remain in the area year-round. To confirm year-round presence, deployment of long-term acoustic detector stations or roost surveys are necessary.

Western Small-footed Myotis (Myotis ciliolabrum) was only confirmed at the Albeni Cove site in August. This species is commonly found roosting in rock crevices, in tree cracks, or buildings (Hoffman et al. 1969, Hendrix et al. 2000). As rock outcrops are less common within the study area, the species may have limited presence due to a lack of suitable roosting habitat.

Long-eared Myotis (Myotis evotis) were confirmed at four sites: Morton River Recreation Area, Morton Slough, Riley Creek, and Springy Point. The species was first detected in May and every subsequent month through August. Long-eared Myotis use of a variety of roost structures throughout the active season including live trees, snags and stumps, buildings, and bridges. It has been found in caves and mines, but may also use rock outcrops (Manning and Jones 1989, reviewed in Maxell 2015 Appendix 5). If suitable hibernacula are found within or in proximity 
to the study area, the species may be present throughout the year. To confirm year-round presence, deployment of longterm acoustic detector stations or roost surveys are required.

Fringed Myotis (Myotis thysanodes) were confirmed at both the Albeni Cover and Morton Slough sites. Both detections occurred in August of 2017. The species is infrequently detected with acoustic detectors or using mist nets (supported by the MTNHP Point Observation Database), consequently the few detections within the study area are not surprising. To-date little is known about overwintering habits of this species in the inland northwest. In similar habitat near Flathead Lake in northwest Montana, a single individual was found hibernating in a cave (D. Bachen, personal observation). Within the project area it is unknown whether the species remains in the region year-round or that some individuals remain and others migrate to more favorable locations to overwinter.

Little Brown Myotis was definitively identified at all sites, and between September 2016 and September 2017. These data indicate the species is widespread during the active season and hibernates in or within proximity to the study area.

Yuma Myotis was confirmed present at seven sites during the active season: Albeni
Cove, Hoodoo Creek, Morton River Access Site, Morton River Slough, Priest River WMA, Riley Creek, and Springy Point. Active season detections occurred in May through September. At the Albeni Dam site the species was detected during the hibernation season. Yuma Myotis use a diversity of roost features in the active season including trees, snags, rock outcrops, buildings, and bridges. Overwintering sites are not well described, but hibernation in rock outcrops may occur (reviewed in Maxell 2015 Appendix 5).

Long-legged Myotis (Myotis volans) was automatically identified by Sonobat to be present at six sites. This species is incredibly difficult to identify using acoustic methods, as almost all calls are indistinguishable from other $40 \mathrm{kHz}$ Myotis species (Maxell 2015a). After hand review, no call sequence could be attributed to Long-legged Myotis. Given that the habitat is similar to locations where we have captured this species during mist net surveys in western Montana (supported by the MTNHP Point Observation Database), we believe it is possible the species is present. To confirm that it is present targeted mist netting should be conducted during the active season as the species is easily captured and identified inhand. 
Table 2. Species detected at each site with the numeric month when detection(s) were confirmed. Note that due to uneven sampling, months without detections may reflect a lack of survey effort rather than true absence.

\begin{tabular}{|c|c|c|c|c|c|c|c|c|c|c|}
\hline Site & $\begin{array}{c}\text { Hoary } \\
\text { Bat }\end{array}$ & $\begin{array}{c}\text { Big } \\
\text { Brown } \\
\text { Bat }\end{array}$ & $\begin{array}{c}\text { Silver- } \\
\text { haired } \\
\text { Bat }\end{array}$ & $\begin{array}{c}\text { Townsend's } \\
\text { Big-eared } \\
\text { Bat }\end{array}$ & $\begin{array}{c}\text { California } \\
\text { Myotis }\end{array}$ & $\begin{array}{c}\text { Western } \\
\text { Small- } \\
\text { footed } \\
\text { Myotis }\end{array}$ & $\begin{array}{l}\text { Long- } \\
\text { eared } \\
\text { Myotis }\end{array}$ & $\begin{array}{l}\text { Fringed } \\
\text { Myotis }\end{array}$ & $\begin{array}{l}\text { Little } \\
\text { Brown } \\
\text { Myotis }\end{array}$ & $\begin{array}{l}\text { Yuma } \\
\text { Myotis }\end{array}$ \\
\hline $\begin{array}{c}\text { Albeni } \\
\text { Falls Dam }\end{array}$ & & & & & & & & & 9 & 9,10 \\
\hline $\begin{array}{l}\text { Albeni } \\
\text { Cove }\end{array}$ & & & & & & 8 & & 8 & 8 & 8 \\
\hline $\begin{array}{l}\text { Hoodoo } \\
\text { Creek }\end{array}$ & 8 & & & & & & & & 8 & 8 \\
\hline $\begin{array}{l}\text { Hornby } \\
\text { Creek }\end{array}$ & & & & & & & & & 7 & \\
\hline $\begin{array}{c}\text { Morton } \\
\text { Slough }\end{array}$ & 6,8 & & 6,8 & & 6,8 & & 6,8 & 8 & 6,8 & 6,8 \\
\hline $\begin{array}{c}\text { Morton } \\
\text { Slough } \\
\text { River } \\
\text { Access } \\
\end{array}$ & 7 & & & 7 & 7 & & 7 & & 7 & 7 \\
\hline Oden Bay & & & & & & & & & 7 & \\
\hline $\begin{array}{c}\text { Pack River } \\
\text { Delta }\end{array}$ & & & & & 6,8 & & & & 6,8 & \\
\hline $\begin{array}{c}\text { Ponder } \\
\text { Point }\end{array}$ & & & & & & & & & 7 & \\
\hline $\begin{array}{c}\text { Priest } \\
\text { River } \\
\text { Recreation } \\
\text { Area }\end{array}$ & & 7 & 5,7 & & 9 & & & & 7 & \\
\hline $\begin{array}{l}\text { Priest } \\
\text { River } \\
\text { WMA } \\
\end{array}$ & 9 & & 9 & & 9 & & & & 7,9 & 9 \\
\hline $\begin{array}{l}\text { Riley } \\
\text { Creek }\end{array}$ & & & 6 & & & & 6 & & 8 & 8 \\
\hline $\begin{array}{c}\text { Springy } \\
\text { Point }\end{array}$ & 7 & & 5 & & 5,7 & & 5 & & 5,7 & 5 \\
\hline
\end{tabular}

\section{Species Activity Trends}

Using the call attributes returned by Sonobat as indices of activity across all sites, the most active species were in the genus Myotis. Due to the relatively low auto-identification rates and hand confirmation of species for these sites we have chosen to report these activity indices by call class rather than species. Within the active season $40-50 \mathrm{kHz}$ bats, including all Myotis species had the highest total number of bat passes across the study area $(13,479)$. Larger bats such as Hoary, Big Brown, Silver-haired, and Townsend's Bigeared Bats echolocate in the $20-30 \mathrm{kHz}$ range, and across the study area only 826 calls were recorded within this group. 
The long-term station placed at Albine Falls Dam over the winter of 2016-2017 recorded relatively few call sequences (153), and all were in the $40-50 \mathrm{kHz}$ range. Only two species were identified at this location, Little Brown Bat and Yuma Myotis. Unfortunately, much ambient ultrasonic noise was present at the site, presumably from the nearby dam and associated infrastructure. This triggered the detector/recorder and resulted in the internal memory cards being filled by late December restricting the recording period to approximately two months.

\section{Conservation AND MANAgement}

\section{Conservation Status of Detected Species}

The Silver-haired Bat, Hoary Bat, Townsend's Big-eared Bat, and Little Brown Myotis are listed as Idaho Species of Greatest Conservation Need (SGCN) under the Idaho Comprehensive Wildlife Conservation Strategy (Idaho Department of Fish and Game 2005). The remaining species detected within the project area are not included on this list, but have a state rank of S3. This designation indicates that these species are potentially at risk of extirpation due to declining numbers or threats to persistence. Townsend's Bigeared Bat and Fringed Myotis are listed as sensitive by the US Forest Service within Region 1. No species found within the study area is currently listed as federally threatened or endangered.

\section{Implications for White-Nosed Syndrome Monitoring}

To-date, the presence of Pseudogymnoascus destructans (Pd) and associated White-Nose Syndrome (WNS) have not been detected in Idaho (Whitenose syndrome occurrence map - by year 2017). However, detections of Pd and WNS within approximately $400 \mathrm{~km}$ of the project site in King County, Washington (Lorch et al. 2016) have increased the urgency for establishing baseline metrics to assess future impacts on resident bats. Of the 10 species detected at sites within the project area, three have been shown to develop WNS when exposed to $\mathrm{Pd}$. These species are the Big Brown Bat, Little Brown Myotis, and Yuma Myotis. Additionally, the Silverhaired Bat and Townsend's Big-eared Bat have been shown to carry Pd, but not exhibit symptoms of WNS (https://www.whitenosesyndrome.org/abo ut/bats-affected-wns). The remaining Myotis species: California, Long-eared, Western Small-footed, and Fringed have not been shown to carry Pd or develop WNS. Rather than indicating immunity to $\mathrm{Pd}$, the lack of detections of individuals with this disease is likely a result of their western distribution that has not overlap with affected areas. As many other Myotis species are impacted by WNS, it is probably best to consider these species as susceptible until proven otherwise.

Our presence data and average activity levels may serve as a baseline for future monitoring efforts to document the impacts of $\mathrm{Pd}$ when it eventually reaches western Idaho. Establishment of baselines before the disease invades this area are important to allow assessment of the impacts on bats within this region. Without pre-WNS baselines, assessment of the impacts of the 
disease on the abundance and distribution of susceptible species is not possible.

Future surveys should seek to determine if the species found during this work are still present within the study area. Although the short-term deployments make the activity data difficult to use as a baseline due to low numbers of nights surveyed, average bat passes per night may be an adequate metric for future monitoring if the disease has a significant negative impact. If sites that reduce the likelihood of vandalism can be found, we recommend that future acoustic monitoring include long-term stations capable of gathering robust activity data across both the active and hibernation seasons. As both the California Big-eared Bat and Long-legged Myotis are difficult to detect with acoustic methods, targeted mist net surveys of creeks and ponds off of the river or lake and flight corridors within forested areas should be considered as well as age and sex data on all species. Finally, projects focusing on identifying active season roosts within both natural and artificial structures, hibernacula, and monitoring known roosts to provide additional baseline data to inform management decisions.

\section{Conservation of Roosts and Other} Landscape Features Important for Bats Conservation and management of roost features used by bats within ACOE managed lands near Albeni Falls Dam is likely to have the biggest impact on local populations. Roosts occur in a variety of natural and anthropogenic features including crevices and cracks in rock outcrops, caves, and both live and dead trees, and buildings, bridges, and mines. Based on the species we determined to be present within the study area, literature documenting roost preferences (see Maxell 2015 for a comprehensive review of known roost types by species), and life history of these species, we recommend the following actions for species conservation within the study area:

1. Maintain potential roost trees including large diameter trees, snags and partially dead trees that provide cavities or loose bark for animals to roost in unless they pose a hazard to people in the immediate area. If removal is necessary, wait until the late fall or winter to remove trees suspected or known to support roosting bats.

2. Before modification of any buildings or bridges, conduct surveys to establish whether the structures are used as roosts. These surveys could include searching for guano deposits and urine staining on the interior or exterior of structures, and examining crevices and sheltered areas for roosting bats. If feasible conduct exit counts at dusk at potential exit points from the structure. If bats are found and exclusion is desired, follow best practices for exclusion (e.g. http://www.batcon.org/resources/f or-specific-issues/bats-inbuildings/excluding-a-colony) and place alternative roost structures (bat boxes) in the local area to compensate for the loss of roosting habitat. 
3. Surveys to determine bat use of other potential roosts including but not limited to rock outcrops, caves, and mines should be conducted prior to any modification.

4. Avoid disturbance of known maternity roosts between May and July and known hibernaculum between October and April. 


\section{LiteratuRe Cited}

Agranat, I. 2014. Detecting bats with

ultrasonic microphones: understanding the effects of microphone variance and placement on detection rates. Unpublished white paper. Wildlife Acoustics, Maynard, MA. $14 \mathrm{p}$.

Arguez, A., I. Durre, S. Applequist, R.S. Vose, M.F. Squires, X. Yin, R.R. Heim Jr, T.W. Owen. 2012. NOAA's 1981-2010 US Climate normals: an overview. Bulletin of the American Meteorological Society 93: 1687-1697.

Arnett, E.B., W.K. Brown, W.P. Erickson, J.K. Fiedler, B.L. Hamilton, T.H. Henry, A. Jain, G.D. Johnson, J. Kerns, R.R. Koford, C.P. Nicholson, T.J. O'Connell, M.D. Piorkowski, and R.D. Tankersley, Jr. 2008. Patterns of bat fatalities at wind energy facilities in North America. Journal of Wildlife Management 72(1): 61-78.

Bachen, D.A., B.A. Maxell, E. Whittle. 2017. Measurements, Body Condition, and Reproductive Status of Bats Captured in Montana, northern Idaho, and western South Dakota. Montana Natural Heritage Program Report. 13 p.

Idaho Department of Fish and Game. 2005. Idaho Comprehensive Wildlife Conservation Strategy. Idaho Conservation Data Center, Idaho Department of Fish and Game, Boise, ID.

Barclay, R.M. and L.D. Harder. 2003. Life histories of bats: life in the slow lane.
Pp. 209-256 In: T.H. Kunz and M.B. Fenton (eds.) Bat Ecology. Chicago: University of Chicago Press. 779 p.

Blehert, D.S., J.M. Lorch, A.E. Ballmann, P.M. Cryan, and C.U. Meteyer. 2011. Bat White-Nose syndrome in North America. Microbe 6(6): 267-273.

Britzke, E.R., E.H. Gillam, and K.L. Murray. 2013. Current state of understanding of ultrasonic detectors for the study of bat ecology. Acta Theriologica 58:109117.

[COSEWIC] Committee on the Status of Endangered Wildlife in Canada. February 3, 2012. Emergency assessment concludes that three bat species are endangered in Canada. COSEWIC Press Release accessed on the internet at:

http://www.cosewic.gc.ca/eng/sct7/Ba t Emergency Assessment Press Relea se e.cfm

Frick, W.F., J.F. Pollock, A.C. Hicks, K.E. Langwig, D.S. Reynolds, G.G. Turner, C.M. Butchkoski, and T.H. Kunz. 2010. An emerging disease causes regional population collapse of a common North American bat species. Science 329: 679-682.

Hendricks, P., D.L. Genter, and S. Martinez. 2000. Bats of Azure Cave and the Little Rocky Mountains, Montana. The Canadian Field Naturalist 114:89-97. 
Hoffman, R.S., D.L. Pattie, and J.F. Bell. 1969. The distribution of some mammals in Montana. II. Bats. Journal of Mammalogy 50(4):737-741.

Kunz, T.H., E.B. Arnett, W.P. Erickson, A.R. Hoar, G.D. Johnson, R.P. Larkin, M.D. Strickland, R.W. Thresher, and M.D. Tuttle. 2007. Ecological impacts of wind energy development on bats: questions, research needs, and hypotheses. Frontiers in Ecology and the Environment 5(6):315-324.

Kunz, T.H., J.D. Reichard, Friends of Blackwater Canyon, Wildlife Advocacy Project, Bat Conservation International, Center for Biological Diversity, and Myer Glitzenstein and Crystal. December 16, 2010. Status review of the Little Brown Myotis (Myotis lucifugus) and determination that immediate listing under the Endangered Species Act is scientifically and legally warranted. http://www.bu.edu/cecb/files/2010/12 /Final-Status-Review.pdf

Lorch, J.M., C.U. Meteyer, M.J. Behr, J.G. Boyles, P.M. Cryan, A.C. Hicks, A.E. Ballmann, J.T.H. Coleman, D.N. Redell, D.M. Reeder, and D.S. Blehert. 2011. Experimental infection of bats with Geomyces destructans causes whitenose syndrome. Nature 480: 376-378.

Lorch, J.M., J.M. Palmer, D.L. Lindner, A.E. Ballmann, K.G. George, K. Griffin, S. Knowles. 2016. First detection of bat white-nose syndrome in western North America. mSphere 1(4):00148-16.
Manning, R.W. and J.K. Jones, Jr. 1989. Myotis evotis. Mammalian Species Account 329:1-5.

Maxell, B.A. Coordinator. 2015. Montana Bat and White-Nose Syndrome Surveillance Plan and Protocols 20112016. Montana Natural Heritage Program. Helena, MT 205 p.

Parsons, S. and J.M. Szewczak. 2009. Detecting, recording, and analyzing the vocalizations of bats. Pp. 91-111 In: Kunz, T.H. and S. Parsons. Ecological and behavioral methods for the study of bats. 2nd edition. Johns Hopkins University Press. Baltimore, MD.

Shump, K.A. Jr. and A.U. Shump. 1982. Lasiurus cinereus. Mammalian Species Account 185:1-5.

U.S. Fish and Wildlife Service. 2012. North American bat death toll exceeds 5.5 million from white-nose syndrome. News Release.

U.S. Fish and Wildlife Service. 2016. Endangered and Threatened Wildlife and Plants; 4(d) Rule for the Northern Long-Eared Bat. Federal Register 81(9): 1900-1922.

Washington Department of Fish and Wildlife. 2017. White-nose Syndrome Update.

https://wdfw.wa.gov/conservation/he alth/wns/. Accessed December $18^{\text {th }}$, 2017. 
White-nose syndrome occurrence map - by year (2017). Data Last Updated

10/12/2017. Available at

https://www.whitenosesyndrome.org/

resources/map 
Appendix 1

Average Nightly Bat Passes by Site and Month 


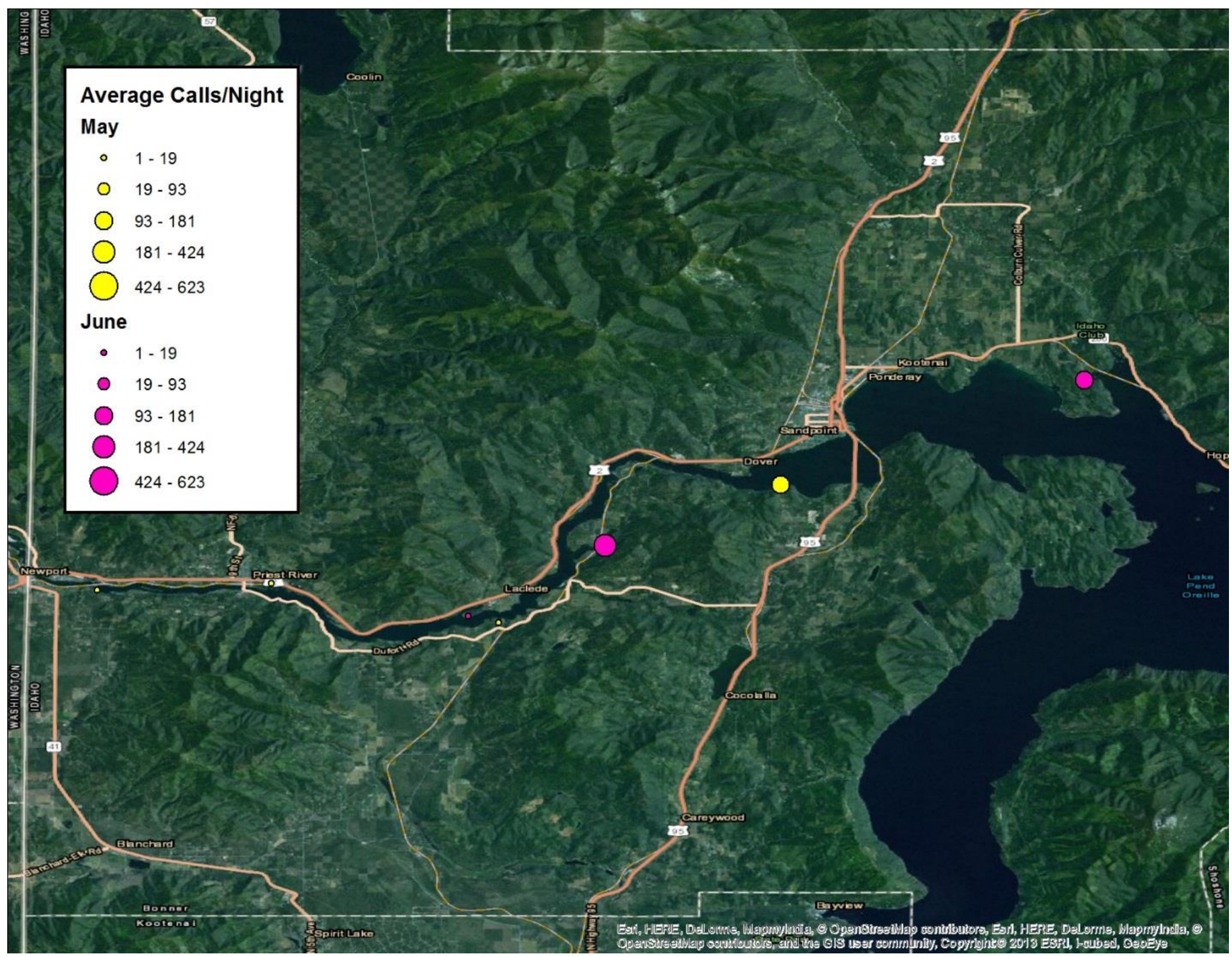




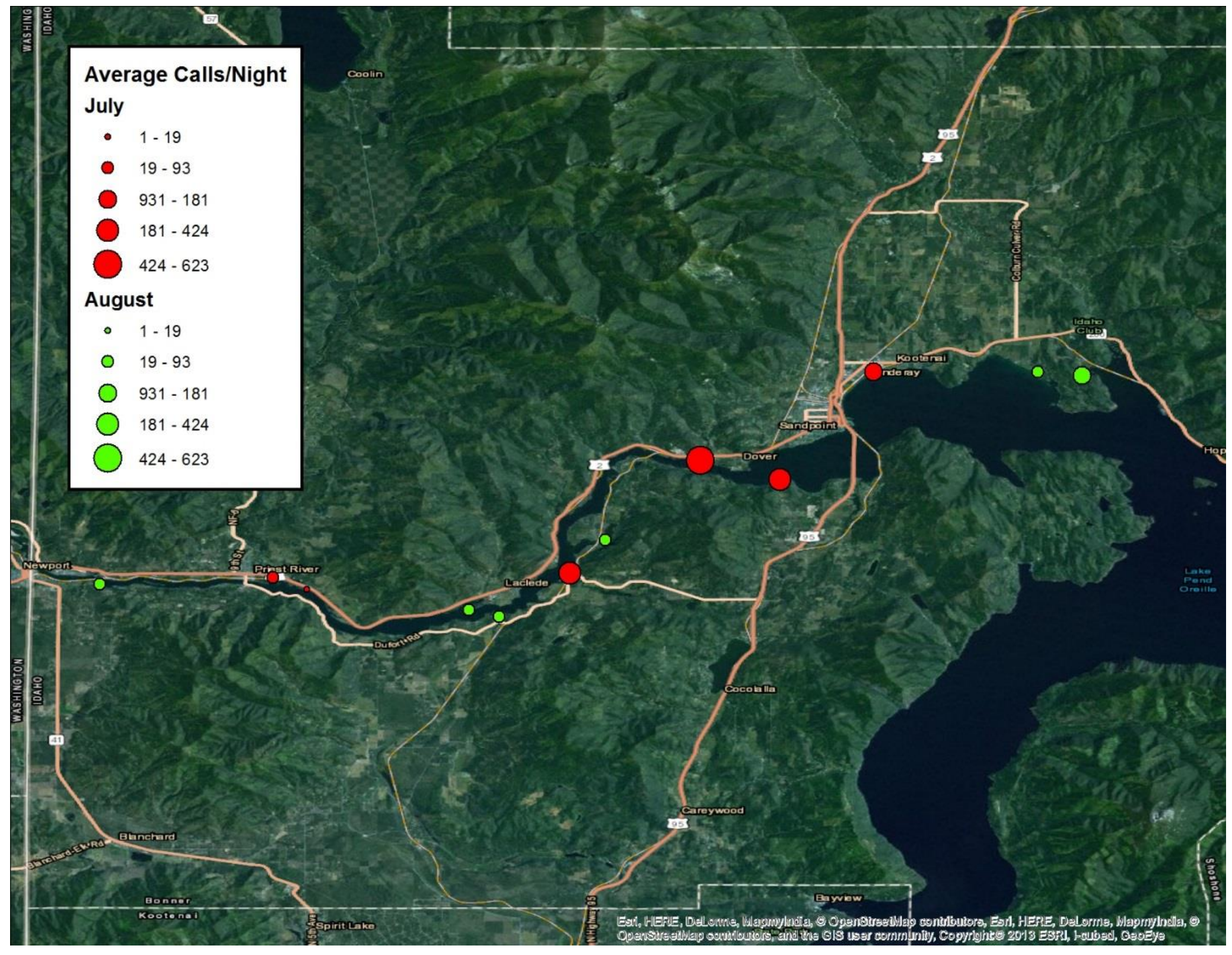


Appendix 2

Species Detections Across Acoustic Monitoring Sites 


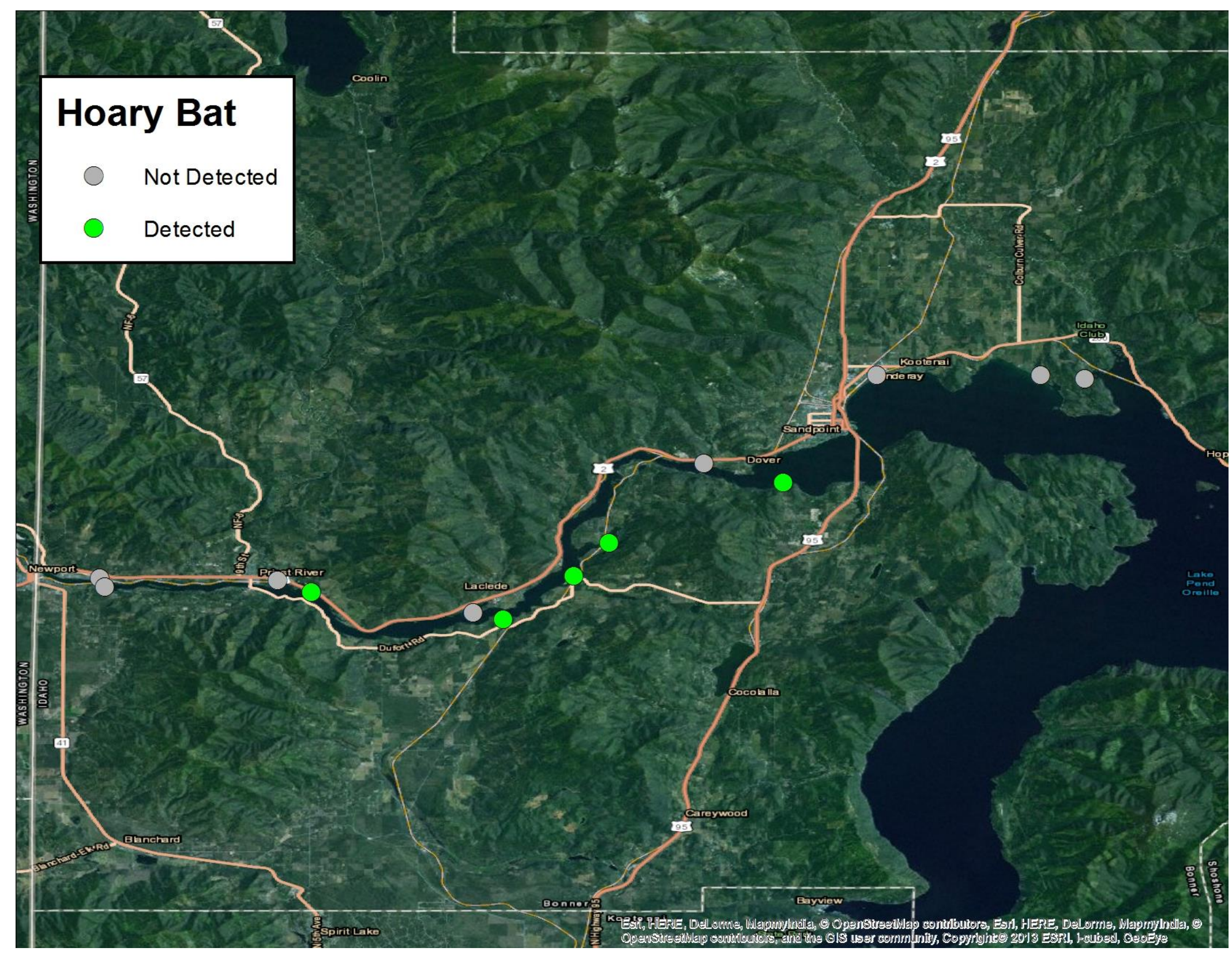




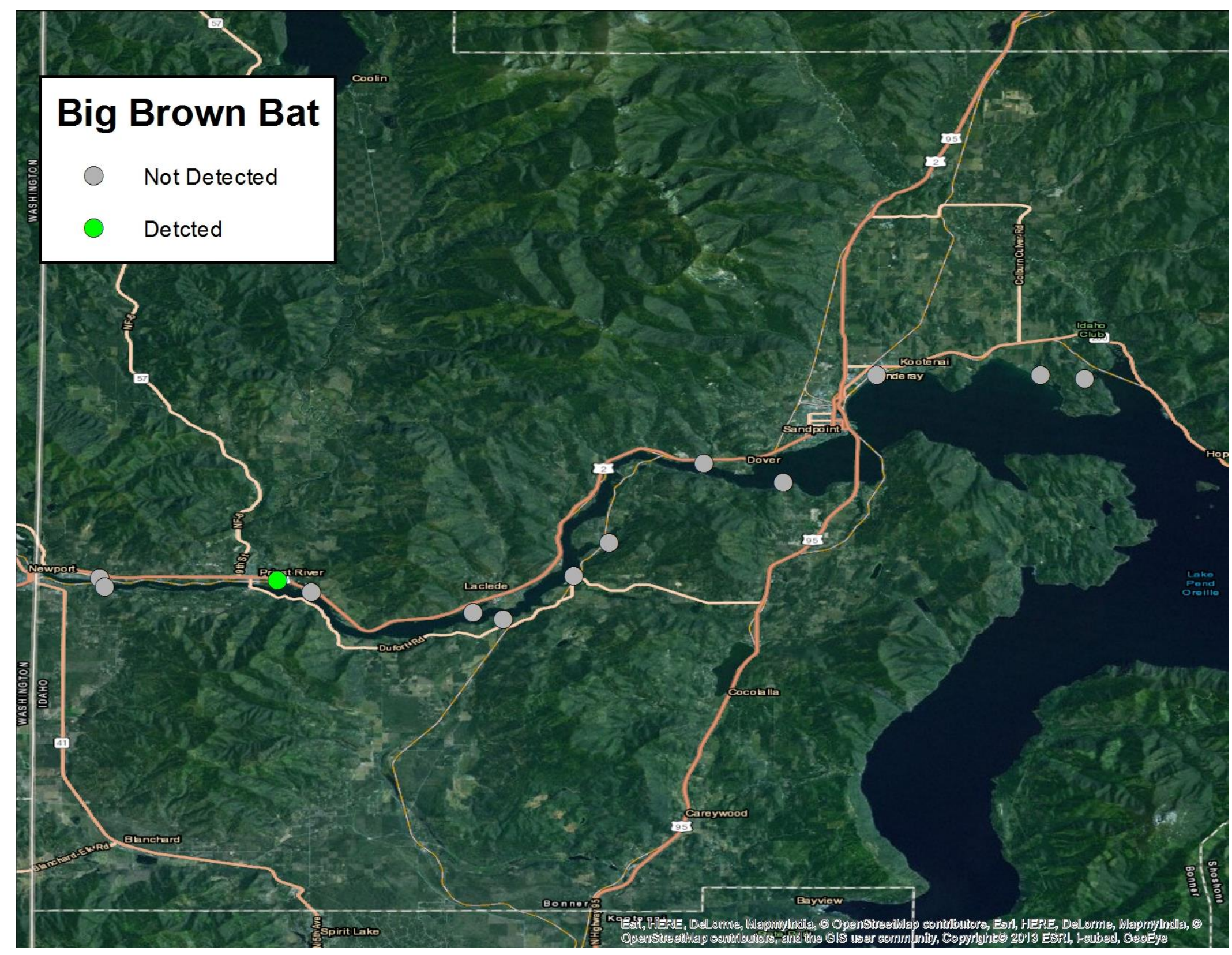




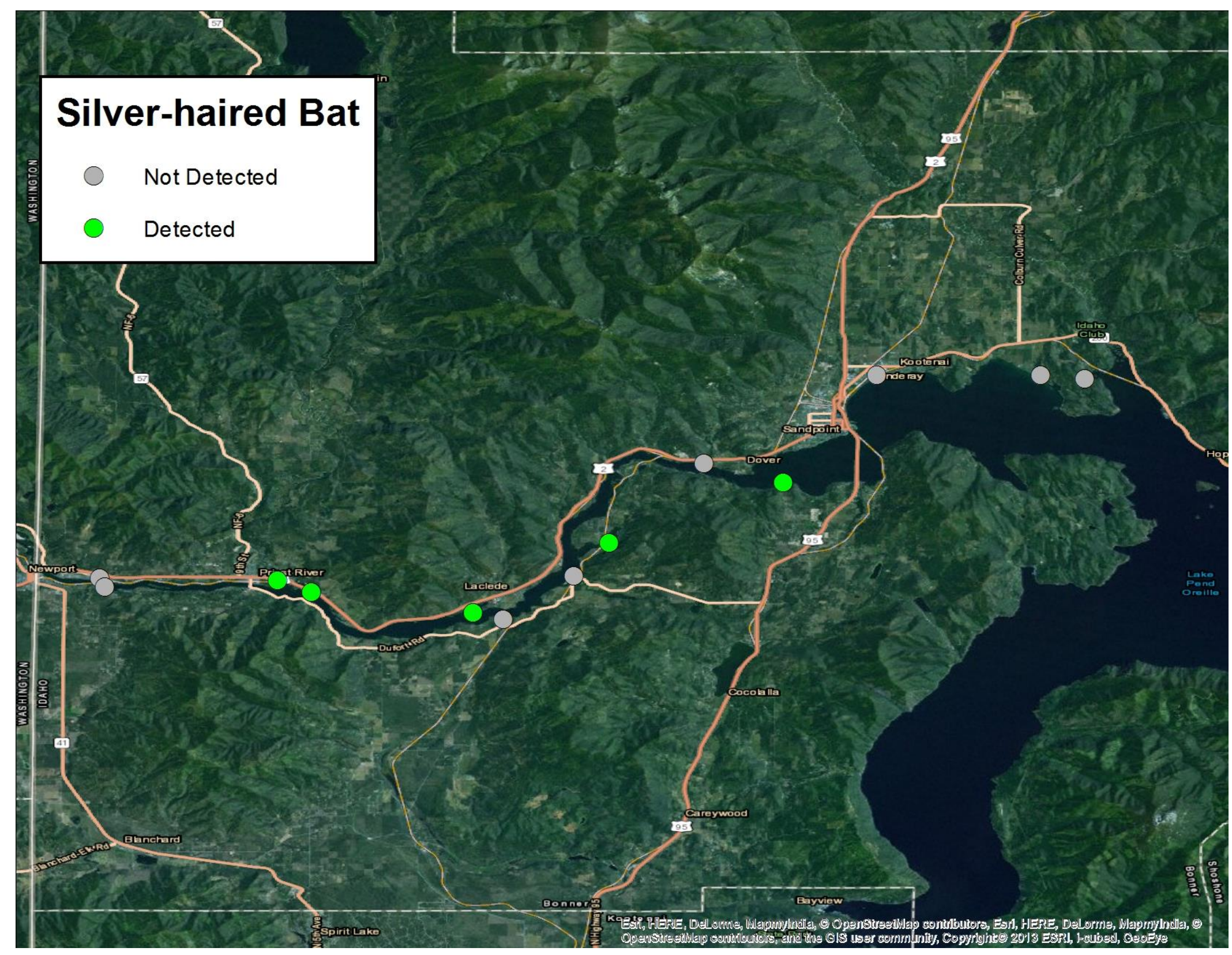




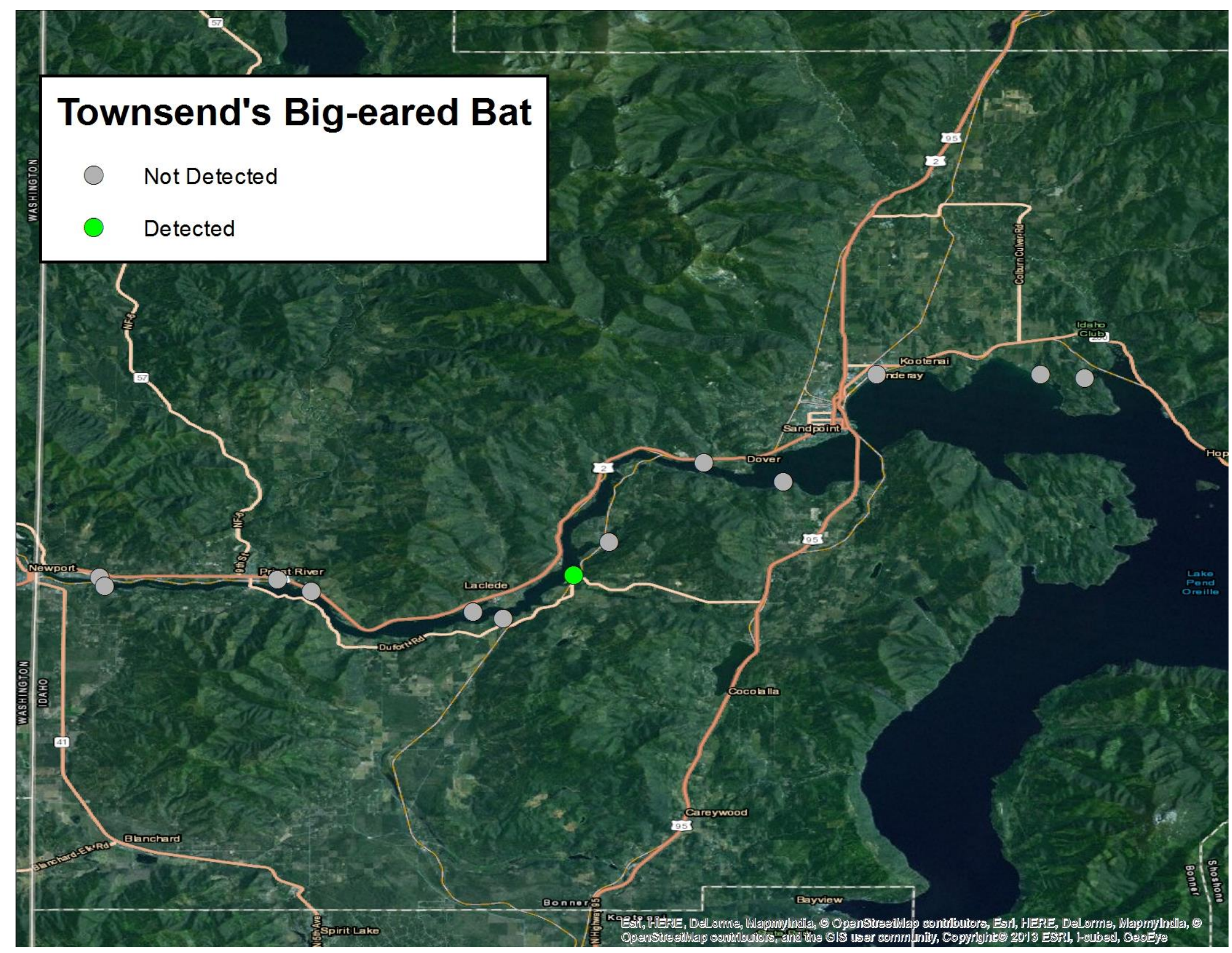




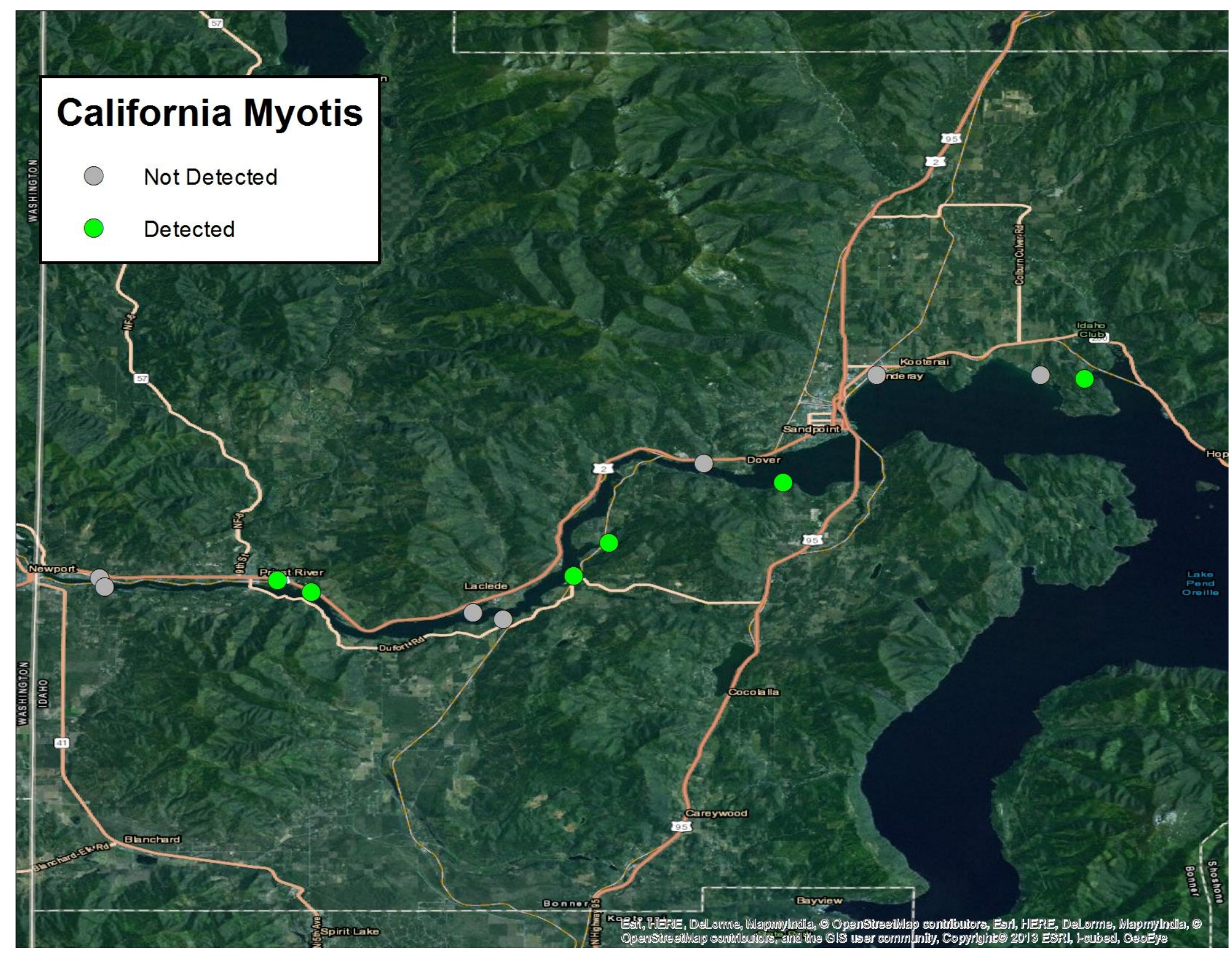




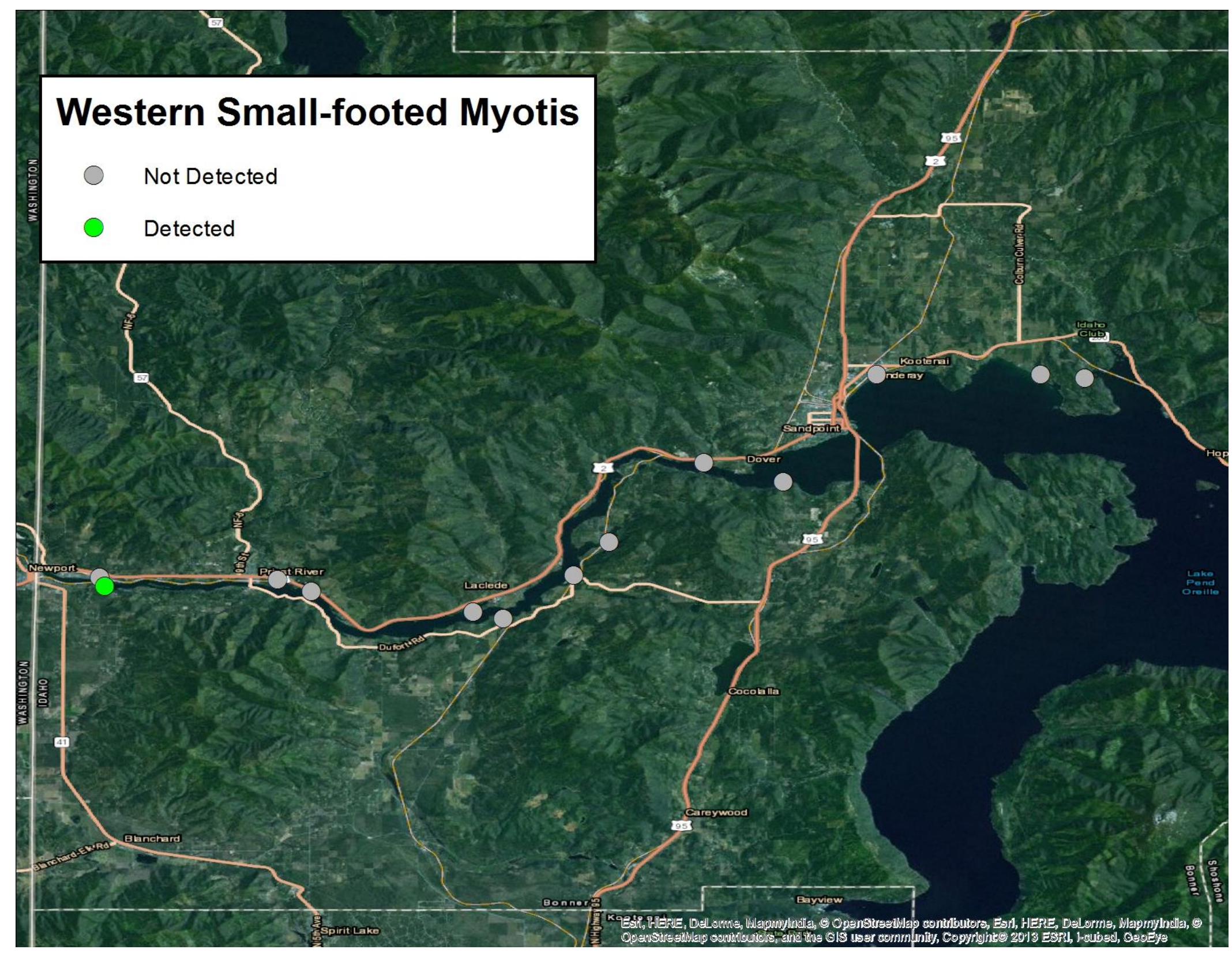




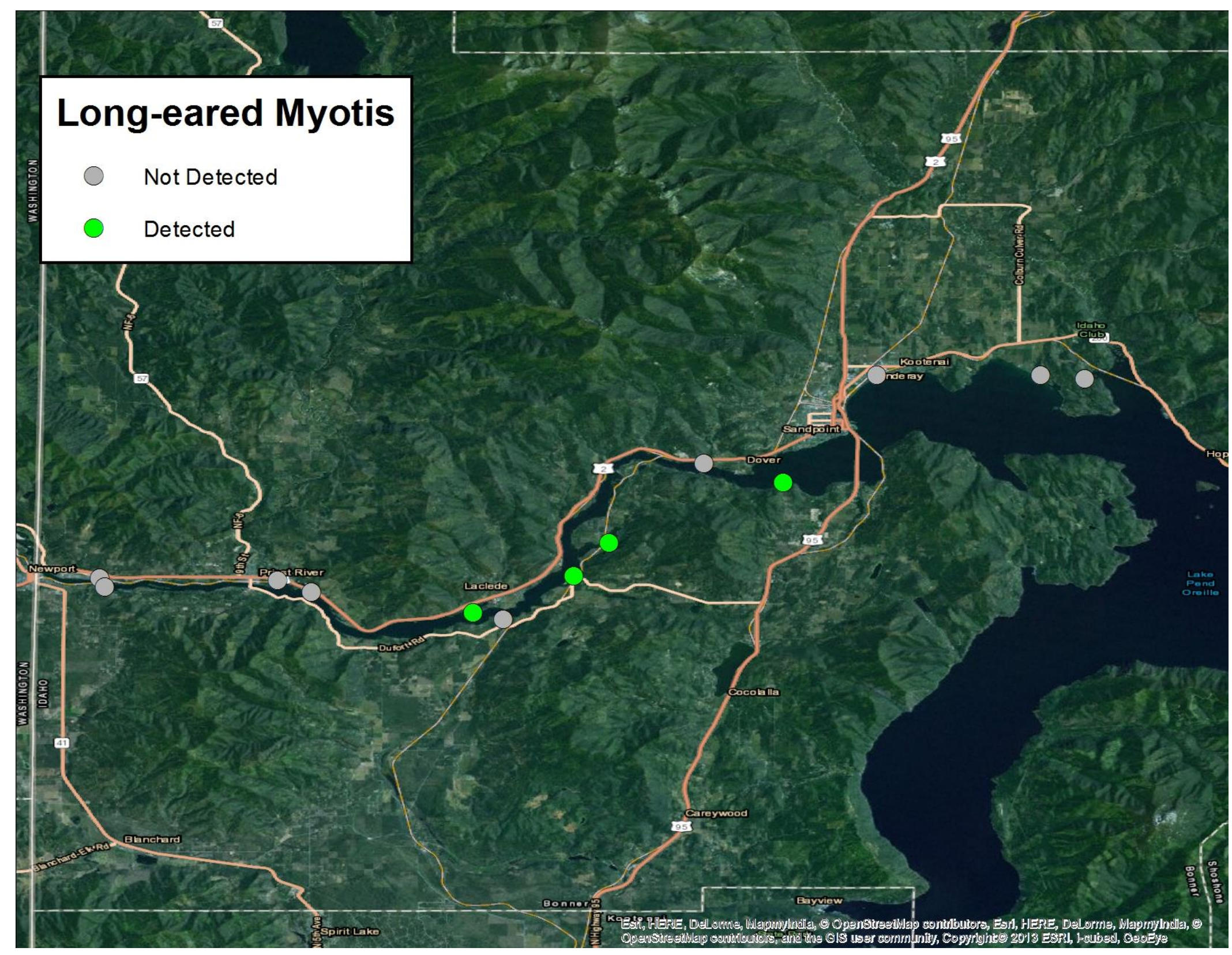




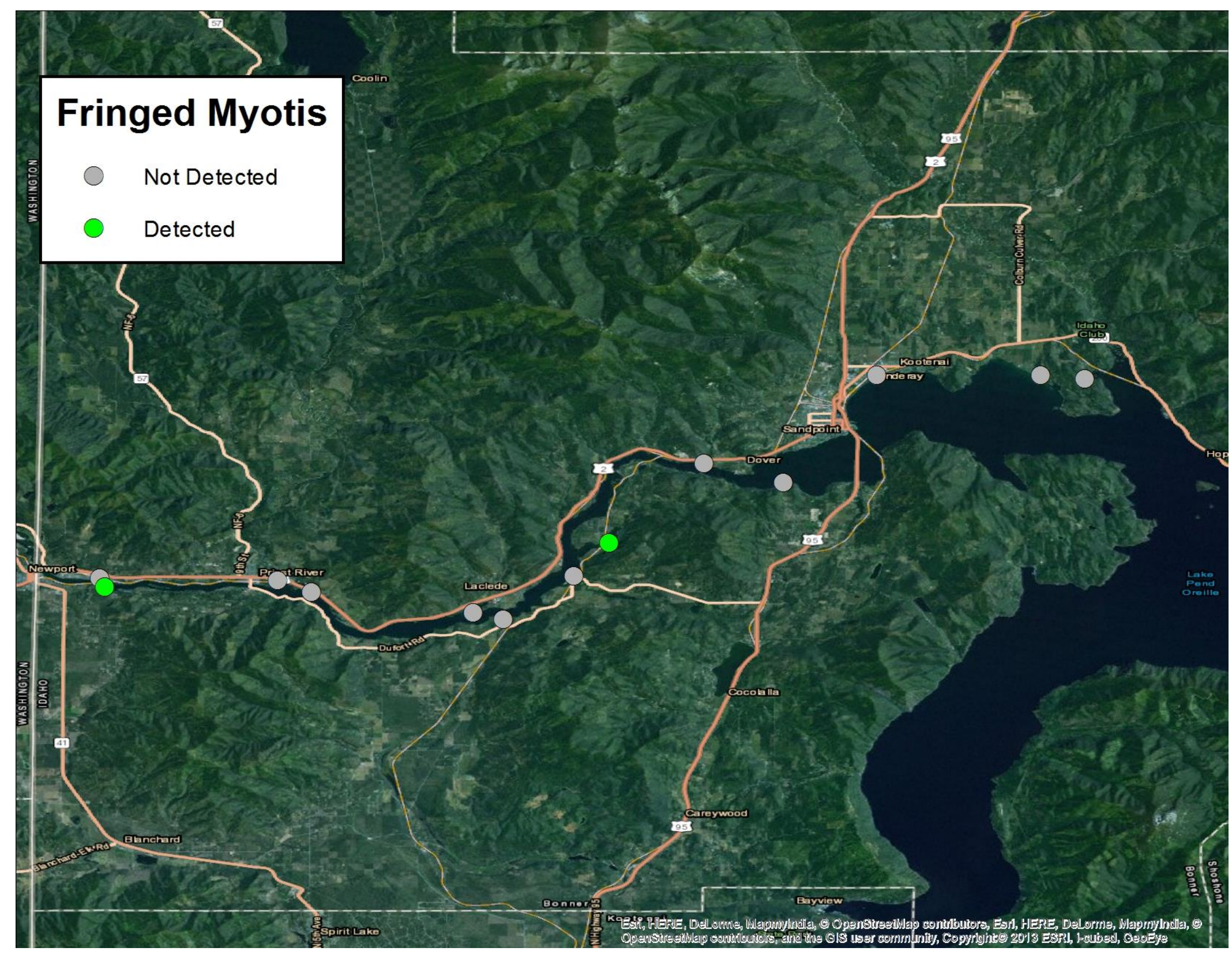




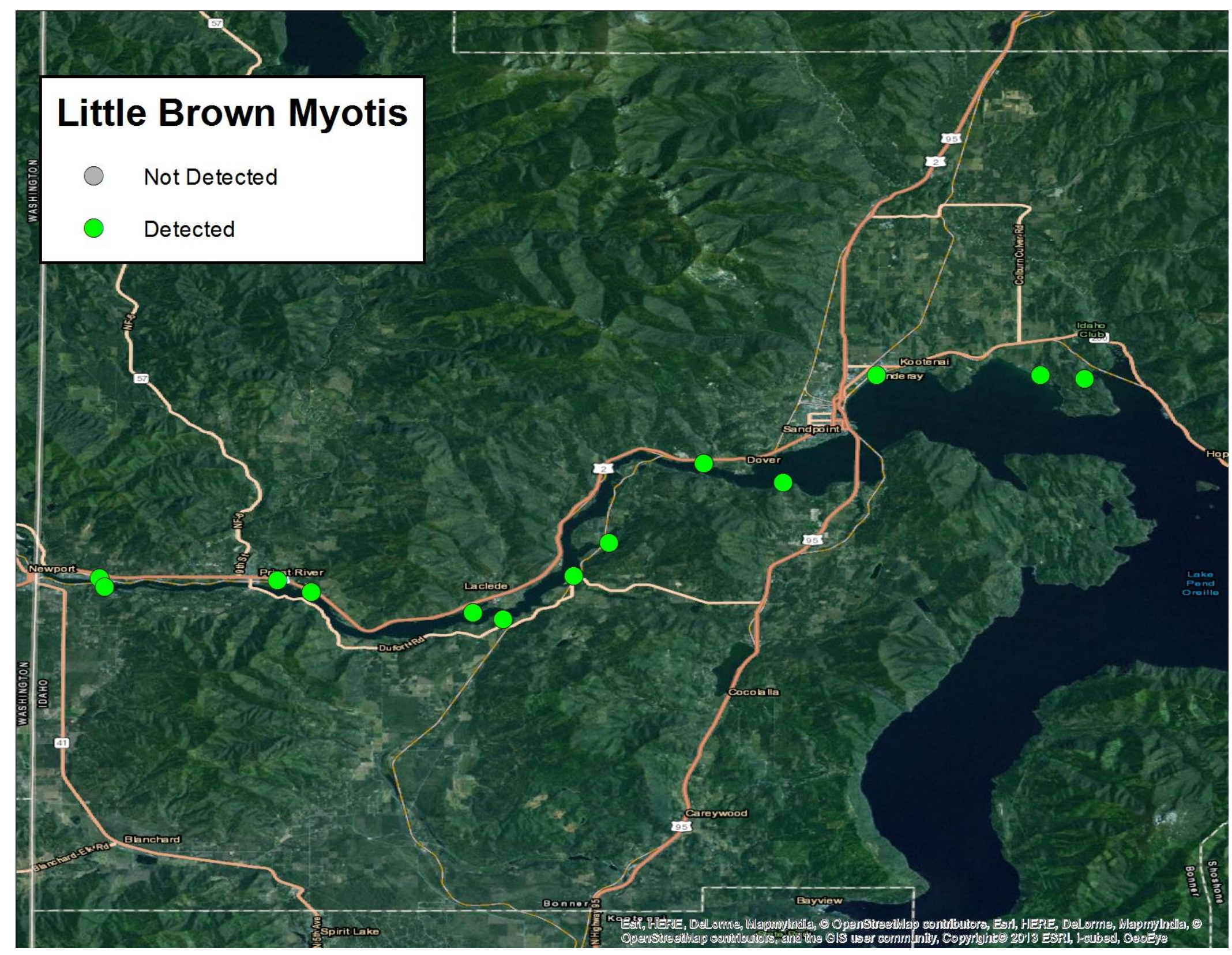




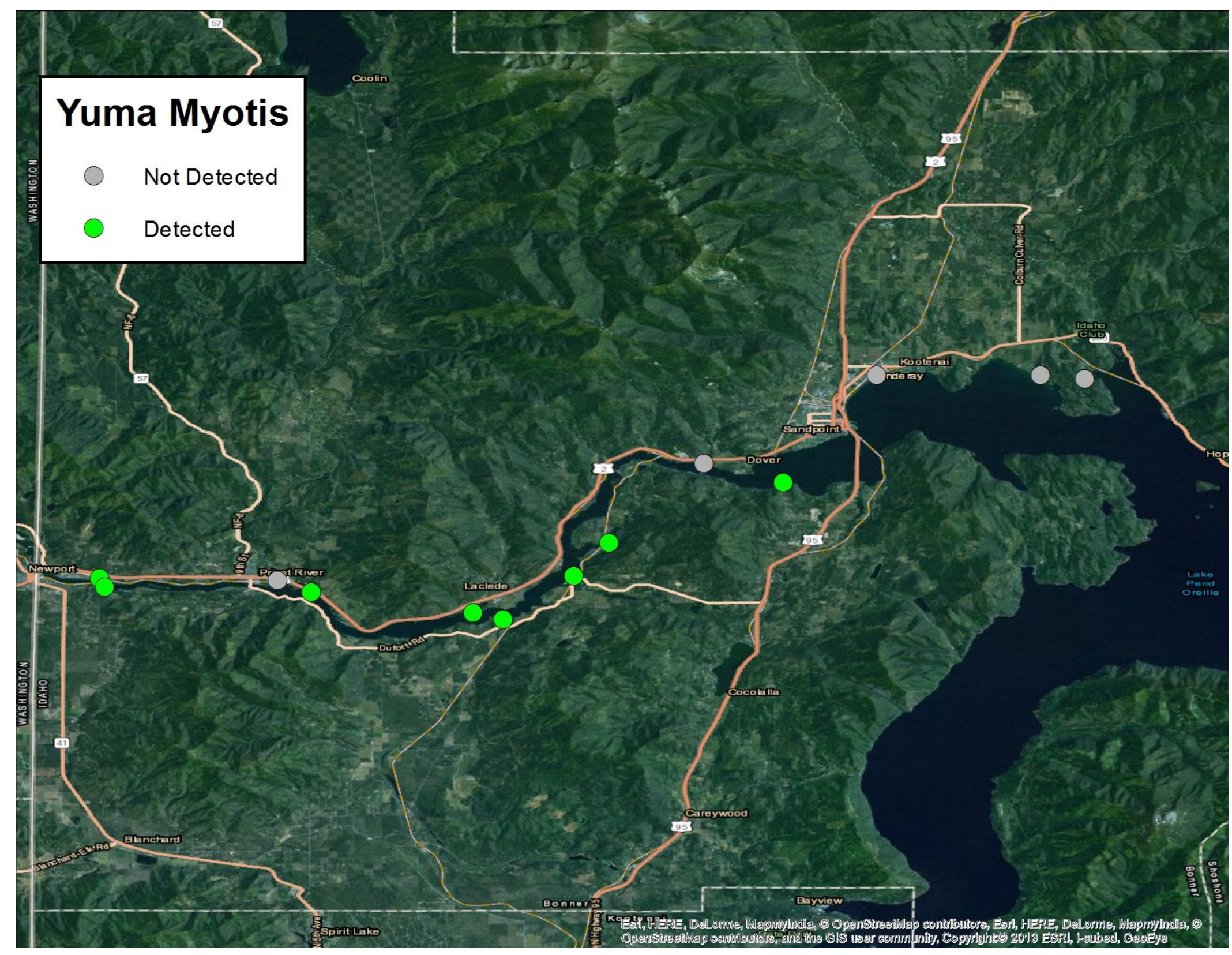

